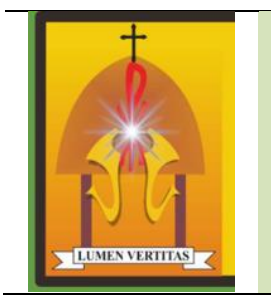

Original article

\title{
KEKATOLIKAN SEKOLAH KATOLIK MENURUT PANDANGAN GEREJA
}

\author{
Herman P. Panda \\ Program Studi Ilmu Filsafat, Fakultas Filsafat, Universitas Katolik Widya Mandira \\ Email: hermanpanda02@gmail.com
}

\begin{abstract}
In this article the author presents the views of the Catholic Church herself about the identity of Catholic schools. This view is spread in a number of Church documents both issued by the Vatican II and by the Pope and Roman Dicasteries. According to this view, Catholic schools have a basic call to educate children and young people to become individuals who have integrity, wisdom and firm faith. For this reason, every Catholic School must continue to maintain a supernatural vision, a strong anthropological foundation, an integral education, the spirit of unity and togetherness of all those involved in the educational process and sustained by the living testimony of the teachers.
\end{abstract}

Keywords: pendidikan, visi adikodrati, antropologi kristiani, bijaksana, berintegrasi, beriman

\section{Pendahuluan}

Dalam salah satu kunjungan lima tahunan (ad limina visit) para uskup Amerika Serikat ke Vatikan, Bapa Suci Yohanes Paulus II mengingatkan bahwa "amatlah penting lembaga-lembaga Katolik menjadi benar-benar Katolik: Katolik dalam pemahaman diri dan identitas mereka." Lebih lanjut Bapak Suci mengatakan: "semua mereka yang ambil bagian dalam karya kerasulan dari lembaga-lembaga tersebut, termasuk mereka yang tidak beriman Katolik, mesti menunjukkan apresiasi yang jujur dan penuh penghargaan terhadap misi yang merupakan inspirasi sekaligus alasan utama keberadaan lembagalembaga tersebut"1.

Walaupun kata-kata di atas ditujukan kepada para uskup Amerika Serikat, tetapi pada dasarnya peringatan Paus ini berlaku pula untuk semua lembaga Katolik di mana pun berada, termasuk sekolah-sekolah Katolik. Sebab karena

\footnotetext{
${ }^{1}$ Paus Yohanes Paulus II, “Address to the Bishops of the United States of America coming from the Province of Portand in Oregon", June 24, 2004.
}

Copyright (C2019 Herman P. Panda. This is an open access article distributed the Creative Commons AttributionNonCommercial-ShareAlike 4.0 International License 
identitas Katoliknya, sebuah sekolah Gereja, sebagaimana terdapat dalam Katolik secara niscaya merupakan sarana berbagai dokumen. penyaluran nilai-nilai Kerajaan Allah bagi anak-anak dan kaum muda. Dan apa yang dikemukakan Paus di atas bukanlah hal baru. Konsili Vatikan II dalam Pernyataan tentang Pendidikan Kristen Gravissimum Educationis telah menegaskan: "Sekolah Katolik, sementara sebagaimana harusnya membuka diri bagi kemajuan dunia modern, mendidik para siswanya untuk dengan tepat guna mengembangkan kesejahteraan masyarakat di dunia, serta menyiapkan mereka untuk pengabdian demi meluasnya Kerajaan Allah, sehingga dengan memberi teladan hidup merasul, mereka menjadi bagaikan ragi keselamatan bagi masyarakat luas",2.

Lalu, apakah tanda bahwa sebuah sekolah Katolik benar-benar mewujudkan kekatolikannya? Di bawah ini akan dikemukakan lima prinsip yang diharapkan ada dalam sekolah Katolik, sebagai penentu identitas katoliknya. Kelima prinsip ini disusun berdasarkan pemahaman saya atas ajaran Magisterium

\footnotetext{
${ }^{2}$ Konsili Vatikan II, Pernyataan Tentang Pendidikan
} Kristen Gravissimum Educationis, dalam R.

\section{Visi adikodrati}

Sebuah sekolah Katolik memiliki visi adikodrati sebagai sumber inspirasi utama. Dasar kuat Gereja membangun sebuah filosofi tentang pendidikan seperti ini adalah pemahaman bahwa pendidikan merupakan proses pembentukan manusia seutuhnya, secara khusus manusia yang hatinya senantiasa terarah kepada Tuhan. Sekolah Katolik berusaha mendidik siswa supaya kelak menjadi warga masyarakat yang baik, yang mampu memperkaya lingkungan hidupnya dengan ragi injili, tetapi sekaligus tidak lupa akan tujuan terakhir hidupnya yaitu menjadi warga "dunia yang akan datang". Dengan kata lain, sekolah Katolik memiliki tujuan utama yaitu mendorong pertumbuhan manusia Katolik yang baik, yang mengasihi Allah dan sesama, dan dengan demikian berada di jalan menuju kekudusan.

Hal ini penting di tengah-tengah dunia yang semakin dirongrong oleh semangat keduniawian di mana Tuhan 
ditempatkan pada pinggiran kehidupan. Bila kita gagal mempertahankan visi adikodrati seperti di atas, segala pembicaraan kita tentang kekatolikan sekolah Katolik, tidak lebih dari sekadar "gong yang berkumandang dan canang yang gemerincing" (1 Kor 13:1).

\section{Dasar antropologis yang kuat}

Sekolah Katolik didirikan di atas dasar pemahaman yang benar tentang martabat manusia kristiani. Dengan menekankan tujuan adikodrati peserta didik, tercakup pula di dalamnya suatu penghargaan mendalam atas perlunya mendidik anak-anak menuju kesempurnaan sebagai citra Allah (Kej 1: 26-27) dalam segala dimensinya. Iman Katolik mengajarkan bahwa rahmat Allah bekerjasama dengan kodrat manusia. Dalam hal ini terdapat kerjasama yang saling melengkapi antara hal yang adikodrati dan yang kodrati. Untuk itu, semua yang terpanggil untuk mengabdi di sekolah-sekolah Katolik perlu memiliki pemahaman yang mendalam tentang pribadi manusia.
Secara khusus mereka yang mengajar atau menjadi pembimbing di sekolahsekolah Katolik, perlu memiliki pemahaman menyeluruh tentang manusia (tidak hanya sebatas bidang ilmu tertentu), terutama memperhatikan kebutuhan-kebutuhan untuk perkembangan baik kodrati maupun adikodrati peserta didik.

Berkali-kali dokumen Tahta Suci mengulangi pentingnya suatu filosofi tentang pendidikan yang dibangun di atas dasar antropologi kristiani yang mantap. Dalam dokumen berjudul "Awam Katolik di Sekolah-sekolah: saksi iman"3 Tahta Suci menjelaskan bahwa dalam dunia yang pluralis dewasa ini, pendidik Katolik harus secara sadar menginspirasi kegiatannya dengan konsep kristiani tentang manusia, dalam kesatuan dengan kuasa mengajar Gereja. Konsep tersebut meliputi pembelaan hak-hak azasi manusia tetapi juga konsep tentang pribadi manusia sebagai anak Allah, yang memiliki kebebasan penuh, tertebus dari dosa oleh Kristus, dan tujuan tertingginya adalah kesatuan total dengan Allah

${ }^{3}$ The Sacred Congregation for Catholic Education, Lay Catholics in Schools: Witnesses of Faith, 15 Oktober 1982 (Roma: Libreria Editrice Vaticana, 1982). 
melalui kasih. Manusia seperti itu juga mengembangkan suatu relasi solidaritas dengan manusia lain melalui kasih timbal balik. Selanjutnya manusia dipanggil pula kepada tugas mengembangkan secara penuh segala ciptaan karena dia dikehendaki oleh Penciptanya sebagai tuan atas segala ciptaan lain.

Dokumen-dokumen Tahta Suci yang lain, dengan berbagai cara menegaskan bahwa supaya layak menyandang gelar Katolik sebuah sekolah Katolik harus berdiri di atas dasar Kristus Sang Penebus yang melalui penjelmaannya telah bersatu dengan manusia, termasuk para siswa. Kristus bukan sekadar tambahan pada visi sebuah sekolah Katolik tetapi berada pada pusat, dan menjadi terang yang menerangi setiap siswa yang datang menimba ilmu di sekolah Katolik. Maka sekolah Katolik harus berjuang mewujudkan perkembangan manusia seutuhnya, sebab di dalam Kristus Sang manusia sempurna, segala nilai manusiawi menemukan kepenuhan dan kesatuannya. Di sinilah letak dari karakter khas sekolah Katolik: tugas utamanya adalah memelihara nilai-nilai manusiawi yang bersumber pada figur Kristus sebagai model utama.
Injil dan pribadi Yesus Kristus merupakan inspirasi dan penuntun sekolah Katolik dalam setiap aspeknya: filosofi pendidikannya, kurikulum, kehidupan komunitas sekolah, pengangkatan guru bahkan juga dalam menata lingkungan fisik sekolah. St. Yohanes Paulus II pernah mengatakan: pendidikan Katolik pertama-tama adalah persoalan mengkomunikasikan Kristus dan membantu orang lain untuk menghidupi hidup Kristus.

Bahwa Kristus merupakan dasar dari setiap sekolah Katolik bukanlah hal baru. Akan tetapi pengakuan seperti ini, kadang-kadang kurang didalami. Dengan antropologi kristiani yang mantap, pendidik Katolik dimampukan untuk mengenal Kristus sebagai standar dan ukuran kekatolikan sebuah sekolah Katolik. Kristus merupakan dasar dari seluruh usaha pendidikan dan prinsipprinsip Injil merupakan norma penuntun.

\section{Semangat persatuan dan kebersamaan}

Sekolah Katolik dijiwai oleh semangat persatuan dan kebersamaan. Dokumen-dokumen Gereja juga menekankan aspek komunitas sebuah 
sekolah Katolik, yaitu suatu kenyataan yang berakar pada, baik kodrat sosial pribadi manusia maupun faham Gereja sebagai rumah persatuan dan kebersamaan. Pemikiran tentang sekolah Katolik sebagai sebuah komunitas pendidikan, merupakan perkembangan baik bagi sekolah-sekolah dewasa ini. Konsili Vatikan II dalam Pernyataan tentang Pendidikan Kristen mencatat suatu perkembangan penting dari cara memandang sekolah-sekolah Katolik yaitu perubahan dari perspektif sekolah sebagai sebuah lembaga ke perspektif sekolah sebagai sebuah komunitas. Aspek komunitas ini barangkali merupakan suatu hasil dari kesadaran baru dalam memahami hakikat Gereja sebagaimana dikembangkan dalam Konsili tersebut. Dalam teks-teks Konsili Vatikan II, aspek komunitas pertamatama adalah konsep teologis dan bukan kategori sosiologis. ${ }^{4}$

Ada tiga hal yang Tahta Suci lihat dan harapkan dari perkembangan sebuah

4 Konsili Vatikan II, Konstitusi Dogmatis tentang Gereja, Lumen Gentium, dalam R. Hardawiryana SJ, Dokumen Konsili Vatikan II (Jakarta: Obor, 1993), No. 4, 7, 8, 9; Konsili Vatikan II, Konstitusi Dogmatis tentang Wahyu Ilahi, Dei Verbum, dalam R. Hardawiryana SJ, Dokumen Konsili Vatikan II (Jakarta: Obor, 1993), No. 1; Konsili Vatikan II, Dekret sekolah Katolik sebagai komunitas. Pertama, adanya tim kerja yang kompak atau suatu kerjasama dari mereka yang terlibat dalam pengelolaan sekolah; kedua, interaksi antara siswa dan guru; ketiga, lingkungan fisik sekolah yang asri dan nyaman bagi semua warganya.

Bagi sekolah setingkat Taman Kanak-kanak dan Sekolah Dasar, diharapkan tercipta suatu lingkungan fisik yang nyaman dengan relasi yang hangat antara guru dan siswa bagaikan lingkungan rumah dan keluarga. Pengelola sekolah perlu berusaha mendorong dan menciptakan suasana di mana anak menaruh kepercayaan tinggi pada guru sehingga memungkinkan dia dapat bergiat secara spontan dan kreatif. Hal ini mengandaikan adanya kemauan baik dari semua untuk bekerjasama. Guru awam, Imam dan biarawan/wati yang terlibat dalam pengelolaan sekolah serta orangtua siswa bekerjasama sebagai tim yang kompak untuk kebaikan sekolah, dengan memperhatikan keseimbangan

tentang Kegiatan Missioner Gereja, Ad Gentes, dalam R. Hardawiryana SJ, Dokumen Konsili Vatikan II (Jakarta: Obor, 1993), No. 18; Konsili Vatikan II, Decret tentang Ecumenisme, Unitatis Redintegratio, dalam R. Hardawiryana SJ, Dokumen Konsili Vatikan II (Jakarta: Obor, 1993), No. 2,3,4. 
antara hak dan kewajiban masing- melainkan keseluruhan kurikulum. masing.

Dokumen Konsili Vatikan II berbicara

Filosofi pendidikan Katolik yang tentang "suatu pendidikan integral, yaitu diterapkan dalam setiap jenjang pendidikan yang menjawabi semua pendidikan perlu menaruh perhatian kebutuhan manusia sebagai suatu khusus pada relasi interpersonal di dalam komunitas pendidikan sekolah, terutama pribadi." Itulah sebabnya Gereja mendirikan sekolah-sekolah, karena antara siswa dan guru. Selama masa anak-anak dan remaja, seorang siswa membutuhkan pengalaman relasi personal dengan para pendidik mereka. Apa yang diajarkan akan berpengaruh lebih besar bagi hidup siswa bila ditempatkan dalam konteks keterlibatan personal, kerjasama yang tulus, kesesuaian antara perkataan dan tindakan, serta sikap hidup sehari-hari. Suatu lingkungan pendidikan yang mendorong dan memberanikan siswa akan jauh lebih efektif ketimbang kedisiplinan yang kaku yang malahan dapat menciptakan banyak kemunafikan. Sebuah prinsip pembinaan mengatakan: “yang afektif itulah yang efektif".

\section{Pendidikan yang integral}

Sekolah Katolik berusaha menerapkan pandangan hidup Katolik, tidak hanya melalui pelajaran agama Katolik atau aktivitas pastoral sekolah, sekolah adalah tempat istimewa untuk melaksanakan pembinaan secara keseluruhan bagi pribadi manusia. Suatu pendidikan integral bertujuan membantu perkembangan secara bertahap setiap aspek kemampuan siswa: aspek intellektual, fisik, psikologis, moral dan keagamaan. Pendidikan diarahkan secara langsung bagi perkembangan seluruh pribadi manusia.

Untuk itu, sekolah Katolik perlu senantiasa diilhami dan dituntun oleh semangat Injil. Sebagaimana telah disebutkan di atas, sekolah Katolik dapat mengingkari tujuannya jika gagal menjadikan pribadi Kristus dan InjilNya sebagai pegangan utama. Sebab sesungguhnya, sekolah Katolik mendapatkan dari Kristus segala daya yang perlu bagi karya pendidikannya.

Karena peranan Injil sebagai kekuatan dan penuntun bagi sekolah Katolik, kita mungkin tergoda untuk 
berpikir bahwa identitas dan kekhasan pendidikan Katolik terletak pada kualitas pendidikan agama, katekese dan kegiatan pastoral lainnya. Tetapi sekolah Katolik menjadi Katolik bukan tergantung dari program dan kegiatan seperti itu, walaupun tentu saja baik dan perlu. Sebaliknya sebuah sekolah disebut sekolah Katolik karena mendidik manusia dalam keseluruhan aspek kepribadiannya, serta menyentuh baik kebutuhan kodrati maupun adikodratinya. Sebuah sekolah disebut Katolik bila menyelenggarakan pendidikan yang integral, yang menghasilkan manusia yang memiliki kepenuhan hidup manusiawi dan siap melayani sesama dan juga senantiasa mempersiapkan diri untuk kehidupan yang akan datang.

Gereja Katolik memiliki cara pandang yang khas atas dunia, dan hal ini menginspirasi sekolah-sekolahnya. Pandangan tersebut berupa pandangan hidup yang menyeluruh yang perlu menerangi kurikulum pendidikan. Tahta Suci dalam berbagai dokumen telah

5 Konsili Vatikan II, Konstitusi Pastoral tentang Gereja, Gaudium et Spes, dalam R. Hardawiryana SJ, Dokumen Konsili Vatikan II (Jakarta: Obor, 1993), No. 3, 13; Konsili Vatikan II, Pernyataan tentang menyampaikan hal-hal yang dapat mengilhami dalam penyusunan kurikulum, demi suatu pendidikan integral bagi siswa-siswi. Di antaranya, pertama, prinsip mencari kebijaksanaan dan kebenaran, dan kedua, integrasi antara iman, hidup dan kebudayaan. ${ }^{5}$

4.1. Mencari kebijaksanaan dan kebenaran

Di era teknologi informasi ini, di mana manusia kebanjiran informasi yang dapat diakses kapan saja, sekolah Katolik perlu secara khusus memperhatikan keseimbangan antara pengalaman dan pengertian. Para siswa mungkin memiliki banyak pengalaman tetapi ada risiko kehilangan makna dari pengalaman itu, sebab pengetahuan dan pemahaman jauh dari sekadar akumulasi informasi. Informasi yang banyak belum tentu mengandung pengetahuan yang banyak, dan selanjutnya pengetahuan yang banyak belum tentu mengandung banyak kebijaksanaan. Maka sekolah tidak hanya memberi banyak informasi kepada siswa, apalagi kalau siswa hanya menjadi

Kebebasan Beragama, Dignitatis Humanae, dalam R. Hardawiryana SJ, Dokumen Konsili Vatikan II (Jakarta: Obor, 1993), No. 14. 
penerima pasif. Para guru perlu mengingatkan bahaya "diktator mengajarkan kebijaksanaan hidup relativisme" yang juga menggerogoti kepada siswa, bukan sekadar mentransfer sekolah-sekolah Katolik. "Diktator informasi. Misalnya guru membiasakan relativisme" dapat dipahami sebagai para siswa sedemikian rupa sampai suatu kecederungan yang meluas untuk mereka sendiri benar-benar berhenti pada kebenaran-kebenaran menginginkan belajar dan berhasil pinggiran yang seringkali saling sebagai pelajar mandiri yang tidak terlalu bertentangan satu sama lain, dan tidak tergantung pada guru. Bila seorang guru berhasil dalam hal yang disebut terakhir ini, dia telah menjadikan siswanya bijaksana, bukan sekadar pintar.

Gagasan lain yang sering disampaikan dalam dokumen Gereja adalah keyakinan yang tinggi bahwa betapa pun terbatasnya kemampuan seseorang, dia toh tetap memiliki kemampuan untuk memahami kebenaran. Keyakinan akan kebenaran seperti ini dalam diri pendidik sendiri amat penting. Dalam hal prinsip iman dan moral, guru tidak boleh berpikiran relatif dan ragu-ragu, melainkan dengan pasti membagikan kebenaran itu kepada para siswa, diiringi dengan kesaksian hidup pribadi atas kebenaran tersebut. Paus Emeritus Benediktus XVI pernah berusaha mencari kebenaran yang hakiki. Setiap pendidik harus senantiasa haus akan kebenaran hakiki sebab kebenaran menurut St. Yohanes Paulus II adalah "nilai mendasar, yang tanpanya akan padam kebebasan, keadilan dan martabat manusia"6.

Sekolah Katolik perlu senantiasa berusaha mencari kebenaran, baik dimensi kodrati maupun dimensi adikodratinya. Sekolah melihat pengetahuan manusiawi sebagai suatu kebenaran yang harus ditemukan. Dalam hal ini siswa dididik oleh seseorang yang memahami kebenaran dan tidak hentihentinya mencari kebenaran. Penemuan akan kebenaran kodrati pada akhirnya akan menuntun orang kepada Kebenaran adikodrati yaitu Tuhan sendiri.

\footnotetext{
${ }^{6}$ Yohanes Paulus II, Ensiklik Veritatis Splendor (6 Agustus 1993), dalam Seri Dokumen Gerejawi No. 35 (Jakarta: Departemen Dokpen KWI, 1994), No. 4.
} 
4.2. Integrasi antara iman, hidup dan kebudayaan

Sejak zaman para rasul sampai kini, Gereja berkeyakinan bahwa iman harus terlibat dalam budaya, untuk mentransformasikan budaya itu dalam terang Injil. Sekolah Katolik mendidik para siswa untuk mampu menghubungkan iman Katolik mereka dengan kebudayaan yang mereka hidupi serta mempraktekkan iman tersebut. Hal ini telah dikemukakan dalam satu dokumen yang dikeluarkan oleh Kongregasi bagi Pendidikan Katolik tahun 1997, bahwa pada dasarnya sekolah Katolik perlu memasukkan sebagai satu elemen penting dari program pendidikan yaitu sintesis antara iman dan kebudayaan.

Dalam sekolah Katolik diusahakan perjumpaan sejati antara iman dan akal budi, melalui suatu usaha memahami visi kristiani tentang dunia, hidup, kebudayaan dan sejarah. Sekolah membina siswa di dalam kebudayaan mereka sendiri, dengan menghargai dan mengangkat nilai-nilai baik dari kebudayaan dan mendorong siswa menghidupi nilai-nilai Injil dalam situasi budaya mereka sendiri.
Tetapi diharapkan juga, sejalan dengan perkembangan intellektual siswa, suatu evaluasi kritis atas kebudayaan. Dan iman Katolik dengan prinsip-prinsip dasarnya sesungguhnya merupakan pegangan para pendidik dalam membantu siswa memberikan evaluasi kritis atas kebudayaan. Iman dan kebudayaan memang saling berhubungan erat satu sama lain, dan siswa harus dibimbing dalam cara-cara yang selaras dengan perkembangan intellektual mereka, untuk memahami secara benar hubungan tersebut. Prinsipnya, iman tidak dapat diidentikkan dengan kebudayaan mana pun, senantiasa bebas dari kebudayaan mana pun, tetapi harus terus menerus menginspirasi setiap kebudayaan yang dimasukinya.

\section{Ditopang oleh kesaksian hidup para guru}

Sebagaimana telah disinggung beberapa kali di atas, sekali lagi di sini dikemukakan tentang pentingnya peranan guru yang amat menentukan identitas katolik sebuah sekolah Katolik. Para gurulah yang memiliki 
tanggungjawab menciptakan suatu iklim yang khas sebuah sekolah Katolik, baik secara pribadi maupun dalam kesatuan dengan komunitas sekolah. Bahkan tidak berlebihan bila dikatakan bahwa terpenuhinya tujuan sebuah sekolah Katolik sebagian besar tergantung dari para guru. Karena itulah beberapa dokumen Gereja menekankan pentingnya panggilan guru dan peranan khas guru bagi misi Gereja. Menjadi guru adalah sebuah panggilan, dan bukan sekadar pelaksanaan suatu profesi.

Secara singkat dapat dikatakan bahwa mereka yang terlibat dalam pengelolaan sekolah Katolik, adalah pribadi-pribadi yang berintegritas. Bagi yang beriman Katolik, selain memiliki integritas kepribadian, mereka juga adalah orang-orang yang teguh beriman, setia pada Gereja dan menghidupi sakramen-sakramen Gereja. Memang pasti ada kesulitan-kesulitan yang dihadapi. Misalnya berhubungan dengan kekurangan tenaga guru yang handal tetapi di lain pihak juga berbenturan dengan kesaksian hidup sebagian kecil guru yang kurang mendukung. Bagaimana pun, kita tidak harus tergoda untuk kompromistik, lalu mengurbankan prinsip yang akhirnya mengganggu identitas sekolah Katolik.

Sekolah Katolik membutuhkan guru yang bukan saja memiliki kompetensi keilmuan, tetapi juga memiliki pemahaman yang benar atas hakikat dan kekhasan sekolah Katolik. Maka cara paling utama mempertahankan identitas sekolah Katolik adalah menyeleksi secara saksama calon guru yang akan diterima di sekolah-sekolah Katolik, yaitu mereka yang sungguh memahami ethos Katolik dan secara enthusias memperjuangkannya.

Selain itu pendidik dari berbagai tingkatan pendidikan diharapkan menjadi teladan bagi para siswa, dengan secara nyata menghidupi nilai-nilai Injili. Anakanak sekolah hanya bisa mengalami keindahan nilai-nilai Injili dan mencintai Gereja, bila menyaksikan teladan hidup para guru dan pembina mereka yang lebih dahulu menghidupi nilai-nilai tersebut. Kata-kata Paus Paulus VI amat penting diterapkan di sini: "manusia zaman modern lebih sepenuh hati mendengarkan kesaksian hidup, daripada mendengarkan para guru, dan bila para guru toh didengarkan, itu hanya karena para guru berbicara dari kesaksian hidup mereka". 


\section{Kesimpulan}

Gereja melalui berbagai dokumen, melihat di dalam sekolah-sekolah Katolik suatu warisan yang amat berharga, sekaligus peranan tak tergantikan dalam menjalankan misi Gereja terutama misi pendidikan yang integral bagi kaum muda dan anak-anak. Maka usaha mempertahankan dan menjamin keberlanjutan identitas Katolik yang sejati merupakan tugas yang terus menerus dilaksanakan oleh setiap sekolah Katolik, betapa pun besarnya tantangan yang dihadapi. Saya yakin, karena kekatolikan sebuah sekolah Katolik maka sampai kini masih mendapatkan kepercayaan bukan hanya umat beriman Katolik sendiri tetapi juga umat beragama lain. Para orangtua mempercayakan anak-anak mereka dalam pendidikan sekolah-sekolah Katolik karena yakin bahwa anak-anak tersebut akan dididik menjadi manusia bijaksana, berintegritas serta beriman.

\section{Daftar referensi}

Konsili Vatikan II, Pernyataan Tentang Pendidikan Kristen Gravissimum Educationis, dalam R. Hardawiryana SJ (penerj.),
Dokumen Konsili Vatican II (Jakarta: Obor, 1993)

-------, Konstitusi Dogmatis tentang Gereja, Lumen Gentium, dalam R. Hardawiryana SJ, Dokumen Konsili Vatikan II (Jakarta: Obor, 1993)

-, Konstitusi Dogmatis tentang Wahyu Ilahi, Dei Verbum, dalam R. Hardawiryana SJ, Dokumen Konsili Vatikan II (Jakarta: Obor, 1993).

--------, Dekret tentang Kegiatan Missioner Gereja, Ad Gentes, dalam R. Hardawiryana SJ, Dokumen Konsili Vatikan II (Jakarta: Obor, 1993).

-------, Decret tentang Ecumenisme, Unitatis Redintegratio, dalam R. Hardawiryana SJ, Dokumen Konsili Vatikan II (Jakarta: Obor, 1993).

-------, Konstitusi Pastoral tentang Gereja, Gaudium et Spes, dalam R. Hardawiryana SJ, Dokumen Konsili Vatikan II (Jakarta: Obor, 1993).

--------, Pernyataan tentang Kebebasan Beragama, Dignitatis Humanae, dalam R. Hardawiryana SJ, Dokumen Konsili Vatikan II (Jakarta: Obor, 1993).

The Sacred Congregation for Catholic Education, Lay Catholics in Schools: Witnesses of Faith, 15 Oktober 1982 (Roma: Libreria Editrice Vaticana, 1982).

Yohanes Paulus II, Ensiklik Veritatis Splendor (6 Agustus 1993), dalam Seri Dokumen Gerejawi No. 35 (Jakarta: Departemen Dokpen KWI, 1994).

------, "Address to the Bishops of the United States of America coming 
from the Province of Portand in Oregon", June 24, 2004. 